\title{
The Right to Keep and Bear Arms, Ghana
}

\author{
Ishmael Norman \\ Institute for Security, Disaster and Emergency Studies Sandpiper Place, Langma, Ghana \\ Email: ishmael_norman@yahoo.com
}

How to cite this paper: Norman, I. (2018) The Right to Keep and Bear Arms, Ghana. Advances in Applied Sociology, 8, 668-688. https://doi.org/10.4236/aasoci.2018.810040

Received: September 3, 2018

Accepted: October 26, 2018

Published: October 29, 2018

Copyright $\odot 2018$ by author and Scientific Research Publishing Inc. This work is licensed under the Creative Commons Attribution International License (CC BY 4.0).

http://creativecommons.org/licenses/by/4.0/

\begin{abstract}
The 1992 Constitution provides explicit instructions to the citizens of Ghana to defend it. That is to say, the citizens are inured with the correlative constitutional right to acquire arms, to keep and to bear them in anticipation of national defense. Despite this charge, the legislative framework has, for a considerable length of time, placed administrative restrictions on gun ownership that undermine the constitutional grant to citizens to even acquire arms. The National Commission on Small Arms and regional conventions such as Ecowas Convention on Small Arms and Light Weapons, have confusing nomenclature and idiosyncratic definition for legal and illicit gun ownership that complicate the right to bear arms. This investigation attempts to show to what extent the constitutional mandate had been overlooked and encroached upon, and how the encroachment can be clawed back to enhance Article 3 rights of the citizens under the 1992 Constitution of Ghana.
\end{abstract}

\section{Keywords}

Right to Keep and Bear Arms, Immunity against the Defense of the Constitution, National Commission on Small Arms, Ghana

\section{Introduction}

The right to bear arms is not only guaranteed by the 1992 Constitution of Ghana for the defense of the nation, but it is part of the fundamental and inherent rights of every individual for self-defense and self-preservation (Magna Carter of 1215; English Bill of Rights, 1689; US Bill of Rights, 1791; McDonald v. City of Chicago, 561 U.S. 742, 2010; Caetano v. Massachusetts, 572 U.S., 2016). The national Constitution provided that, citizens have "the right and duty at all times;" "to defend the Constitution, and in particular, to resist any person or group of persons seeking to commit any of the (enumerated) acts in Article 3" of the 1992 Constitution. The enumerated acts include prohibition against the establishment 
of a one-party state, suppression of the lawful political activity of any person or group, violent overthrow of government, abrogation of the Constitution or any part of it, and, or any offence of high treason (1992 Constitution of Ghana, 1992). The articulation of these values in the Constitution is not meant to be whimsical. They emerged out of real events in the history of Ghana such as forced military take-over and the suspension of the national constitution on several occasions in the past.

A brief recap of the national history with military takeovers would illustrate the underlying rational for the constitutional grant to citizens to keep and bear arms, beyond the basic statutory right to own a gun given by several pieces of legislation in Ghana. In 1957 the $6^{\text {th }}$ of March, Ghana gained independence. Mr. Kwame Nkrumah became its first Prime Minister and later an executive President. Nkrumah's government was interrupted in a military coup in 1966 and his socialist economic policies abandoned by the National Liberation Council (NLC). During the NLC regime (1966-69) attempts were made to reverse Nkrumah's vigorous industrialization policies. The reins of government were soon turned over to the democratically elected Dr. Abrefa Busia (1969-71). Busia continued the NLC's monetary reforms and trade liberalization policies of the International Monetary Fund (IMF) and World Bank (Gockel \& Vormawor, 2004 in Norman \& Aviisah, 2015: p. 4).

Despite the apparent progress that was being made to turn the fortunes of the nation around, there was another shocker to the normalization of governance and the rule of law. It was another military coup, which was led by Colonel Kuti Ignacious Acheampong. He ruled henceforth as the chairman of the National Redemption Council (NRC). Among its first acts, was the suspension of the existing Constitution, a revaluation of the Cedi (devalued earlier by Brigadier A. Afrifa in 1967 and the Progress Party of the government of Busia in 1971); a return of control prices to their pre-devaluation levels; a refusal to pay "unjust" foreign loans that had been taken out by previous civilian governments; and a fourfold increase in the minimum wage (Leith \& Söderling, 2003 in Norman \& Aviisah, 2015: p. 4).

While the wage increases were good, they also had an overall incremental effect on the prices of goods and services in the general economy. The Acheampong government proceeded to expand state involvement in the economy and implemented the "operation feed yourself" as a national drive towards greater commitment to agriculture and food self-sufficiency. The NRC's regime which ruled from 1972-1978, was overthrown in a coup on the repercussions of its currency revaluation. The Supreme Military Council (SMC) immediately embarked on currency devaluation in an attempt to salvage the economic crisis in 1978. In fact, so bad were the economic conditions in the country that, a military uprising occurred on June 4th, 1979. This ushered in the government of the Armed Forces Revolutionary Council (AFRC) led by Jerry Rawlings.

The execution by firing squad of three former heads of state and other leading 
political activists sums up the political and economic tension of the era. The AFRC initiated legislation and economic policies that crippled the real economy and financial system that was already crumbling under repressive policies. It finally handed over power to an elected Hilary Limann's government after four months. The Peoples National Party (PNP) stayed in power for barely two years (1979-81) but was ousted by Lt. Jerry Rawlings and his compatriots in the Army on 31st December, 1981, establishing the Provisional National Defence Council (PNDC) government. With his charismatic leadership style and his appeal to Eastern Europe during the cold war, Rawlings initiated the "famous" Economic Recovery Program (ERP), touted as a neoliberal agenda based on the Structural Adjustment Programs (SAP) of the World Bank and IMF in 1983 (Osei, 1999 in Norman \& Aviisah, 2015: p. 4).

All these series of economic-political incidences had negative effect on the sense of well-being, happiness, sense of ownership, education, professional development, promotion, patriotism, nepotism, cronyism and even general health of the population. Beginning from the worsening of conditions from the period immediately after independence through the introduction of the Structural Adjustment Program, through divestiture to the re-introduction of democracy and the rule of law in 1992, there was the general feeling that "Ghana was not a nation for which one should die" (Frimpong-Boateng, 2008, In Norman \& Aviisah, 2015: p. 4). All such political upheavals point to the nascent understanding and appreciation of democracy that the so-called leaders of Ghana had and, in many instances, continue to have and exhibit in managing the national interests and affairs.

The framers of the 1992 Constitution took due cognizance of the fact that "democracy" as a philosophy of life and governance is not yet entrenched in Ghana. Even if Ghana is presumed to be 'democratic', its brand of democracy and the rule of law are not dowered with the fruits of democracy such as the exercise of individual choice, autonomy, capacity, capability and wellbeing. From year to year, the average Ghanaian cannot really say he or she is better off this year compared to the previous year. This is due to a myriad of incapacitating exogenous social, political and economic as well as marketplace, job place and other forces that exert undue pressures on the functioning and capabilities of the average Ghanaian citizen (Norman, 2017).

The framers of the 1992 Constitution did not want the citizens to be surprised by a rag-tag of soldiers, and for that matter, any cell, who might seek to overthrow the government and thus empowered the citizens to rise up in defense, should the unthinkable happen. In order for the citizens to render credible defense, it informs all citizens that they also have immunity against the exercise of their "right and duty" to "do all in their power to restore the Constitution after it has been suspended, overthrown, or abrogated". This is very powerful due to the lack of equivocation and simplicity of the charge. To articulate the import of this charge liberally would mean a call to civil war. That is how far the framers want 
the citizens to go to defend the Constitution.

The spirit contained in the national constitutional right to bear arms, is similar to that contained in the Constitution of the United States of America. The Second Amendment to the US Constitution provides: A well-regulated Militia, being necessary to the Security of a free State, the right of the people to keep and bear Arms, shall not be infringed ( $2^{\text {nd }}$ Amendment: United States Bill of Rights, 1791). Throughout the history of the United States, various courts have attempted to interpret, add on; or nibble away the citizens' right to keep and bear arms through case law and through legislative tinkering, although most have affirmed the citizens' right to bear and carry arms (United States v. Cruikshank, 92 U.S. 542, 1875; Presser v. Illinois, 116 U.S. 252, 1886; District of Columbia v. Heller, 554 U.S. 570, 2008; McDonald v. City of Chicago, 561 U.S. 742, 2010; Caetano v. Massachusetts, 572 U.S., 2016). The right is still intact and has even become stronger due in part to the duty of the legislature and judiciary to preserve the Constitution (Kates, 1983). It is also due in part to the vociferous lobbying activities of the National Rifle Association of America (NRA), an entity which the very mention of its name arouses strong emotional energy on both sides of the American political divide (https://www.romper.com, 2017;

https://www.timeinc.net, 28/2/2018).

It is interesting to note that, in the operationalization of most civil libertarian positive right-claims, in this case, the right to keep and bear arms, Ghana does not have any organized civil society organization to champion the interests and protections of gun owners. There is, however, the Central Firearms Registry (CFR) created in 1955 for the registration and licensing of firearms, which is in the hands of the Police. Notice that, it is difficult to acquire a hand gun legally without the buyer passing through the Police, precisely due to the restrictions placed on gun ownership by the Police and the National Commission on Small Arms. There is also rent-seeking behaviors which strongly associate with barriers to gun acquisition in Ghana (Pokoo, Aning, and Jaye, 2014). Apart from conducting buyer background checks by the Police, and training potential gun owners on gun handling, the Police act as "middlemen" in gun purchases. One can also purchase a hand gun through proxy salesmen to the Police (Procedure to Acquire Firearms and Small arms, NACSA, 2016). This situation makes it difficult to mainstream the expectations of Article 3, 4, and 5 of the 1992 Constitution. Besides the CFR of 1955, there are a dozen more legislation in Ghana designed to control, monitor, and license gun ownership and uses. Obviously, with this many pieces of legislation on gun control, it would be consistent with good public policy for a civil society organization to be interested in coalescing the interests of gun owners within the legal quilt on guns

(http://www.smallarmscommission.gov.gh/pages/whatwedo.php, 16/05/18)

There are about 30-something publicly advertised gun dealers licensed by the Ministry of Interior in the country that sell small arms, pepper sprays, knives and other accessories for personal defense. Several commentators have alleged 
that there is little or no real coordination with such licensed gun dealers and the quantum of guns they import or sell in the nation (Agbozo, 2016). To a large extent, therefore, the import of the legislative grant to the people of Ghana to bear and carry arms, is similar to the $2^{\text {nd }}$ Amendment grant to the citizens of the United States of America to bear and carry arms. The grant was not given for hunting. Ghanaian hunters have used guns for a long time, prior to 1992. The grant was for self-defense and the defense of the Constitution (Kopel, 1995; United States v. Cruikshank, 92 U.S. 542, 1875; Presser v. Illinois, 116 U.S. 252, 1886; Halbrook, 1994; Kopel, 1995; District of Columbia v. Heller, 554 U.S. 570, 2008).

The 1992 Constitution of Ghana provides in Article 4(a) and (b) that:

(4) All citizens of Ghana shall have the right and duty at all times-

a) to defend this Constitution, and in particular, to resist any person or group of persons seeking to commit any of the acts referred to in clause (3) of this article; and

b) to do all in their power to restore this Constitution after it has been suspended, overthrown, or abrogated as referred to in clause (3) of this article.

The Constitution further provides indemnity and immunity clauses in Article (5) through (7) to all citizens who exercise their "right and duty" obligation under the Constitution mentioned in Article (3) and (4).

Despite this observation, there is evidence that national legislation and regional and international conventions (ECOWAS Convention on SALW and at the global level (United Nations Programme of Action on SALW) to which Ghana is a signatory, have already nibbled away the Constitutional right and privilege (Ecowas Convention, 2006). This development is part of the evidence of the encroachment on the Constitutional rights of the people of Ghana. The sovereign shell of Ghana cannot be allowed by regional or international conventions or treaty to poke holes into this sacred embodiment of all that which defines the people of Ghana. Some of such instruments also attempt to nibble away the citizens' right to keep and bear arms in defense of the Constitution and in their own personal defenses. The right to bear arms as given to the people should be held as sacrosanct and should not be downgraded by legislation or common law.

\section{The Reason for This Paper}

The motivations behind this paper were to ascertain to what extent the constitutional grant to bear and carry arms, has been nibbled away by legislative construct or judge made law, and by public policy or by the importation of regional conventions and other international treaties into the legal framework. It is also to help shed light on the creeping nature of such encroachment on the rights of the people and how this can be clawed back. It is discomforting and disconcerting to learn that, "the history of the legislative (construct) on Small Arms and Light Weapons in Ghana revolves around initiative to domesticate international 
legal regime into domestic law to facilitate local enforcement" (Pokoo, Aning and Jaye, 2014:2). Such an approach to national law making, though seemingly efficient, is extremely ineffective in addressing local exigencies without tinkering with the law to suit the national situation. Often the required tinkering is poorly executed by the promoters of the draft bill, and continues on through the various parliamentary readings and sub-committee review of the bill until it is passed into law with all of its avoidable imperfections and defects.

Why is the defense of the 1992 Constitution so important to the citizens' right to keep and bear arms? Admittedly, in the post-modern era of electronic information networks and social platforms, the defense of any social or political value is not only limited to the use of guns and weapons. In some limited circumstances, the use of force or weapon, is necessary due to the nature of the challenge and the behavior of the actors in the situation or conflict. This is the least preferred approach, despite the Constitutional charge. The defense of the constitution of this nation or any other can be done also, through many other means. These include cogent presentation of the narrative surrounding the vexatious issues leading to the conflict in the court of public opinion, besides the use of force. It could also be a dispassionate and unbiased review of the literature of the particular social menace such as what is being discussed in this paper, to ascertain the extent of the encroachment, abuse, or deviation from the desired goal. The constitutional grant to keep and bear arms is part of the overall preparedness strategy of the nation against the singular existential threat of a military take-over. This also means that the citizens need to have sufficient ammunitions, physical strength and mental readiness to respond to any act that might usurp the 1992 Constitution.

Nonetheless, it seems the expectations of the 1992 Constitution is already hampered by the various Acts of Parliament regulating the right to keep and bear arms. There are currently some fourteen or so separate laws on the ownership, or acquisition and operation of handguns and related ammunitions, besides the Ecowas and United Nations Development Program conventions. There is obviously something wrong with the picture of a nation that has not ever conducted a civil war against itself, but has over a dozen laws and legislative instruments to regulate the right to keep and bear arms. Ghana has not ever gone to war against its neighbors since its independence in 1957, except a select few of its military and police personnel that had ever served in benign Peace keeping roles in the Sub-region and elsewhere. Due to the pacifism of Ghana, which underlines its foreign policy and relationship with its neighbors, there are many of our military personnel as well as the police, who through no fault of theirs, may spend their entire military or service careers without ever been placed in war situation apart from Peace keeping forays. Despite their availability for national duty and sacrifice when required, their numbers are finite. The citizens can provide appreciably larger numbers of first responders to the defense of the nation. That is why it is important to the survival of the nation to empower citizens to 
exercise their natural and constitutional right to arms.

\section{Approaches Used to Limit the Citizens' Right to Bear and Carry Arms}

Legislation has been used dating back to the colonial era to curtail and clip the citizens' right to keep and bear arms. Over the years, the nation has built up quite a number of such legislation, namely Arms and Ammunitions Ordinance, 1922, (Cap 253); State Secrets Act, 1962 (Act 101); Arms and Ammunitions Act, 1962 (Act 118); Arms and Ammunitions (Amendment) Act, 1972 (N. R. C. D 9); Arms and Ammunitions Regulation, 1962 (L. I 200); Explosives Regulation, 1972; Customs and Excise and Preventive Service Management law of 1993; Minerals and Mining Act, 2006 (Act 703); Minerals and Mining Regulation of 2012, (L. I. 2177); and the Ghana National Commission on Small Arms, 2007 (Act 736), to mention but a few. Each one of these laws has its own unique mandate which are apposite to that of the National Commission on Small Arm's but operate in different ways and means from that of the National Commission. Each of these Acts and their legislative instruments have different hierarchical structures and resources that the National Commission may not be able to boast of.

The end result is that the National Commission on Small Arms has been given a mandate whose operationalization creates confusion and conflict with other national entities such as the Police to supervise gun ownership and possession. Part of the confusion arising out of the legislative construct can be found in the wholesale importation of material parts of the Ecowas Convention on Small Arms and Light weapons of June 2006 into the national legislation on this important public health issue.

It appears also that very little specific consideration to the national exigencies arising from the use of Small Arms was exercised in the drafting of the law and in the parliamentary debate surrounding the passage of the law that established the Commission. Barely eleven months after the Abuja Convention, the national legislation leading to the establishment of the Commission on Small Arms and Light Weapons of 2007 (Act 736) became law in May, 2007.

The wholesale lifting of important parts of the Ecowas Convention appears to have bequeathed to the national law with a much bigger mandate than was envisioned. The expanded mandate was gratuitous for the control of handguns and weapons in Ghana, without the corresponding expertise, resources and skills to perform that herculean role as provided by Act 736 of 2007.

The broad objective of the Commission was, "to advise (the Minister of the Interior) on the issue and possession of small arms and light weapons and to provide for related matters". If the national legislation had landed on the broad objective and then developed the modalities for achieving controls over the issue and possession of small arms and light weapons as subsidiary objectives, perhaps the Commission would have been more effective. 
The subsidiary objective seems to place the Commission between the controls of the Ministry of Interior and Foreign Affairs, while at the same time inuring the Commission with actual operational responsibilities of "combating and eradicating" illicit trade in Small Arms. How is the Commission supposed to combat and eradicate illicit trade? It has no militia, and no intelligence gathering capabilities. Hierarchically speaking, it was made, de jure, subservient to the Ministry of Interior with the concomitant real administrative controls over Small Arms in the hands of the Police. Such legislative design, provides the opportunity for the work of the Commission to be delayed, its strategies diverted by other entities and its approaches misdirected by the possible egoistic clashes between some Chief-Directors of the Ministry of the Interior and the CEO of the Commission.

Section 2 of Act 736 of 2007 sets out the apparent modalities for combating and eradicating illicit trade in Small Arms, which to all intents and purposes, is not consistent with the actual capabilities and capacities of the Commission currently even in 2018, eleven years after the Commission came into being. The Commission would:

2(2): a) Set in place programs of action to prevent, combat and eradicate the illicit trade in Small Arms and Light Weapons;

b) Ensure that obligations under the Economic Community of West African States were complied with;

The Commission is not part of the Ministry of Foreign Affairs. By legislation, it is under the Ministry of Interior. How was it to ensure that obligations under the Ecowas Convention was complied with?

c) advise the Minister (of the Interior) on formulation of policies and strategies as contained in the Convention on Small Arms and Light Weapons and any other relevant international convention to which Ghana is a party or has acceded to;

How was a Commission charged with domestic responsibilities to "prevent, combat and eradicate the illicit trade in Small Arms" not be given the responsibility for registering and issuing licenses for handguns? By vesting this duty in the Police, the Commission appears not to have any real control over how many guns are in the hands of citizens. Wouldn't it have been more efficient to vest the power to issue gun licenses in the Commission whiles the Police was left with the responsibility for conducting background checks and criminal investigations on potential gun owners?

d) receive and study periodic reports from the Ghana Police Service on the registration and licensing of arms, and

e) perform any other functions related to the object of the Commission.

As if the legislative design defect did not present real operational difficulties to the Commission, but the defective architecture, was buttressed by a regional regulation that had its own enforcement and operational challenges: Ecowas (Abuja) Convention on Small Arms and Light Weapons, Their Ammunition and 
other Related Material of May, 2006.

The national legislation chose to adopt the definitions and nomenclature of the Ecowas Convention as part of the national legal framework without apparent serious interrogation. The Ecowas Convention of 2006 defined Small Arms to mean:

Arms used by one person and which include notably,

- Firearms and other destructive arms or devices such as an exploding bomb, an incendiary bomb or a gas bomb, a grenade, a rocket launcher, a missile, a missile system or landmine,

- Revolver and pistols with automatic loading

- Rifles and Carbines

- Machine guns

- Assault rifles

- Light machine guns

The Commission on Small Arms law, Act 736 of 2007 also defines Small Arms as verbatim as that of the Convention above. This is not unusual in legislative drafting, but credit should have been given to the original Convention or law or regulation or treaty and some amount of tinkering should have been done to design the law to suit local conditions.

Secondly, the motivations behind the use and application of Small Arms are invariably different, from the existential threat posed by machine guns, assault rifles, bombs, grenade and rocket launchers or even missile system. Therefore combining these weapons under the control of an ill-resourced, ill-capacitated Commission with marginal capability for credible combat and eradication of illicit Arms; let alone; Light Weapons, betrays a serious national flaw in legislative drafting.

It is not acceptable national culture to butter pressing national threats with hasty legislation that are both ineffective in providing the required intervention and also unsuccessful in building the expertise needed to solve the same or similar national threats and challenges.

The Commission's definition of Light Weapons is the same as that of the Ecowas Convention, a national legislative culture which is not really proper in tackling the issues that scare us.

According to the Commission, Light Weapon means "portable arms designed to be used by several persons working together in a team and which includes:

a) heavy machine guns

b) portable grenade launchers, mobile or mounted

c) portable anti-aircraft cannons

d) portable anti-tank missile launchers, $r$ rocket launchers

e) portable anti-tank cannons, non-recoil guns

f) portable anti-aircraft missile launcher

g) mortars with a caliber of less than 100 millimeters

It is fair to assume that the Ecowas Convention was drafted with a view to 
combat armed insurrection, civil war, and terrorist activities against the government machinery within West Africa. It is, however, not reasonable to assume that its purposes expected private citizens to acquire and bear portable heavy machine guns, portable grenade launchers, mobile or mounted, portable anti-aircraft cannons, and portable anti-tank missile launchers, and rocket launchers. Assault rifles and guns are not inexpensive. It is not easy to warehouse them and need constant attention. Except an individual is a member of cell of a gang or terror group, assault weapons, anti-aircraft cannons and missile launchers are not in the normal inventory of the average gun enthusiast even in gun holding and owning nation like the United States of America, let alone Ghana.

These are weapons that the average national military rookie, or neophyte police man or woman, may not have ever seen except, perhaps, in pictures and service magazines and journals, let alone handle such a weapon or possess one. Just as such weapons are largely not in use by the national security personnel, perhaps, except those with sophisticated Standard Operating Procedures (SOPs) or job assignments, the average national gun owner has never even seen a hand grenade before except in cinemas, let alone hold and discharge one.

\section{Method and Procedure for the Review}

The author relied on published material on gun acquisition, registration and licensing in Ghana, and the 1992 Constitution as well as the National Commission on Small Arms and Light Weapons of 2017, (Act 736). The researcher did not carry out field research to assess how the Act or the Constitutional grant to citizens to keep and bear arms were being translated on the ground. The researcher conducted searches on the world-wide-web for both grey literature and scholastic articles on the right to keep and bear arms not only in Ghana, but other countries with Common Law traditions.

Other databases were searched for information, including journals such as the Ghana Law Journal for reported cases and other research on the issue, which is generally available in the public domain. Search combinations were used to find relevant literature: "the right to bear arms, Ghana," "annual gun related crime report on Ghana;" "Legislative pronouncements on acquisition, registration and licensing of guns, Ghana," "judicial and juridical protective mechanisms for gun owners, Ghana, only," "best practices of judicial and legislative review of acquisition, registration and licensing of guns", "Access to gun dealers in Ghana", "Statistics on crimes committed by gun owners", "owner notification and licensing registry". The search was expanded to include the "Constitutional controls of gun ownership".

The studies selected met the evaluation criteria adopted for the review of literature in order to find common themes that would enhance the study. It was assumed that licensing and registration modalities had the potential to curtail the right of the citizens to keep and bear arms. The selected material included any report (scholarly paper, opinion, editorial, book chapter, internal post-operations 
reports, and annual reports) or investigations on Small Arms and Light Weapons on Ghana and in the Sub-region.

For best practices the search also covered papers from entities such as the Kofi Annan International Peacekeeping and Center, the National Commission on Small Arms and Light Weapons, and studies by other national researchers and scholars.

In order to perform the analyses of how acquisition, registration and licensing of guns were managed by the NCASA, the researcher focused on 4 sub-themes: 1) the design and reach of the legislative framework on the right of the citizens to keep and bear arms, 2) the NCASA's position on acquisition, registration and licensing of guns, 3) the gaps in the national legislative architecture such as: previous (judicial and legal review mechanisms used to protect or deny gun ownership), and 4) the position of the law on mainstreaming the citizen's right to arms to safeguard the 1992 Constitution.

In addition, the review concerned both the public safety and human rights approaches adopted by the National Commission to consider whether they were sound and effective in preventing the proliferation of illicit guns in the nation. And whether there are national mechanisms to isolate mundane criminal activities without the use of guns or light weapons, from those perpetrated with guns. It also investigated if there was a national policy on owner notification, names reporting in the context of expired licenses and the enforcement mechanism for compliance with the law. Finally, the research focused on the manner and consequences of public education on gun ownership, licensing, and registration.

A review of "grey literature" was performed non-selectively, including an overview of existing policies pertaining to acquisition, registration and licensing of guns. Thirty-five publications that met the inclusion criteria were found. Twenty-five were articles and 10 were reports. An overall score was assigned and the position taken by the paper, report or publication was identified in relation to the objective. A score of $1=$ entirely relevant; $1 / 2=$ somewhat relevant and 0 $=$ not relevant at all were awarded. Papers that received scores above 3.5 out of 5 after the rating were used in the evaluation and were further analyzed. The data was disaggregated into the respective themes for analyses and summarized the findings into their respective units, and interpreted them based upon the author's skills, knowledge and specialization in public health legislation, national security matters and policy management.

\section{Findings from the Literature Review and Analyses of Gun Legislation}

Below is a summary of some of the key flaws in the national legislation, coupled with regional legislation on gun acquisition and ownership as well as registration. These tend to compromise the free exercise of the citizens to keep and bear arms, which may not be consistent with the 1992 Constitution.

There is a constant criminalization and decriminalization processes of gun 
ownership, which has been created by operational instruments, policy and regulations of the agencies such as the National Commission on Small Arms and related matters, the Ghana Police and the Ecowas Convention on Small Arms and Light Weapons.

There is distortion in the statistics of gun ownership due to the short ownership renewal cycles and the automatic classification of guns with late renewals as illicit. Thus depriving their owners the right to free and unencumbered uses and enjoyment of their personal possession.

It is not yet established empirically or otherwise that, there is correlation between legal gun ownership and uptick of crime in the urban, rural and peri-urban areas.

It has not been shown yet, the correlation between illicit guns and the uptick of crime in the urban, rural and peri-urban areas.

It appears the National Commission on Small Arms does not have any program to regularly notify the owners of Small Arms for renewal to help reduce the artificially bloated figure of proliferation of illicit guns in the nation. This weakness is incidentally part of the modus operandi of not only the National Commission on Small Arms but the Ecowas Commission on Small Arms as well.

There is the perennial challenges of knowing the quantum of Small Arms that are in possession of the citizens, the true identities, and locations or domiciles of so-called registered gun owners in Ghana.

Though it appears public education (risk communication) on the risk of, and handling of, guns are some of the core programs of the National Commission on Small Arms. But such public education tends to be intermittent, unfocused to specific public health menace and often removed from the locus of criminal activities involving the use of Small Arms.

The periodic decommission exercise of Small Arms in the various regions of the nation, characteristically nets very few, already out of commission guns needing serious repairs. The decommissioning of guns that are already rendered useless by their owners in such exercises, does not provide the right picture of the real numbers on guns in circulation.

There is no data on crimes committed with Light Weapons such as anti-tank or aircraft launchers, or missiles, or heavy machine guns to necessitate that provision in the law to be placed under the mandate of a unit under the Ministry of Interior.

\section{Discussion and Recommendations}

The mandate of the National Commission on Small Arms and Light Weapons need to be reviewed to correct some of the observations made in this paper and those that have been identified by other researchers. Notice that Act 736 of 2007 is not a big document totaling only 8 pages. That is to say, it consists of half of eight A4 size pages or 4 full size A4 pages. If there is a Legislative Instrument to Act 736, this author did not sight it. By its appearance and design, there are 
many gun related legislation and issues that were not addressed in that Act, or even mentioned by reference. There was no attempt, it seems, to bring all the different legislations on gun control and ammunitions under one law and rationalize the inherent conflicts in the different Acts. There does not seem to be the national awareness that the right of the citizens to defend the 1992 Constitution is a national duty that cannot be spurned at will. Owners of small arms are required to register their guns for a period of one year, and continue to register it annually until they are dispossessed of it although there are other less powerful hunting guns which are exempted from the annual registration process (Pokoo et al. 2014). Part of the reasons for this requirement is rather simple. The Criminal Code of 1960 (Act 29) criminalizes the possession of arms and ammunition without license or registration as a first degree felony. Section 192 addresses the issue of possession of explosives, firearms and ammunition that,

1) Despite the provisions of any other enactment, a person who has in possession, custody or control, without lawful excuse, the proof of which lies on that person, an explosive, a firearm or an ammunition commits a first degree felony.

As soon as the annual registration expires, and before the same gun owner can do the re-registration, during the transition between the date of expiry of the just ended license and the new date of registration, the gun moves from being in legal compliance to illicit status. There are other public health laws on gun control that placed a greater criminal burden on possession of arms. Although enacted before the coming into force of the 1992 Constitution, it appears the Arms and Ammunition Act, 1972 (NRCD 9) is still valid law in as much as it is not inconsistent with the provisions of the 1992 Constitution.

Section 11 of the Arms and Ammunition Act states:

Where any firearms, arms of war, munitions of war or ammunition are, without the proper authority,

a) found in the possession of a person,

b) kept in a place other than a public warehouse, or

c) unlawfully kept in a private warehouse,

2) that person or the occupier of that place, or the owner of the place or any other person keeping them, commits an offence unless that person, occupier, or owner can prove that they were deposited there without the knowledge or consent of that person, occupier or owner.

Obviously, the charge to citizens to bear and carry arms provided by the 1992 Constitution had in mind the utility of the arms so kept and borne. That without ammunitions the guns are merely toys. Therefore, it appears there is already a conflict in the legal framework respecting the issue of ammunitions. The registration and licensing of arms do not disinherit the person who had previously legally purchased ammunitions to surrender it. In fact, and as a practical matter, the registration and re-registration allows gun owners the right to purchase more or fresh ammunitions without regard to the number of ammunitions for a rifle, for example, the person had previously. There is really no practical way of controlling the number of ammunitions a person has to be used for one regis- 
tered gun.

\subsection{Distortion in Gun Statistics}

Part of the reasons why the annual registration was invented was to help the government's revenue collection efforts as demonstrated by the Arms and Ammunitions (Amendment) Act of 1996 (Act 519). In the Arms and Ammunition Amendment Act, various classes of guns and related material are levied according to their class or explosive yields and trajectories.

Research conducted by the Commission on Small Arms in collaboration with the Kofi Annan International Peacekeeping and Training Centre (KAIPTC) in 2014, and with financial and technical support from the United Nations Development Programme (UNDP), found that there were 2.3 million Small Arms in circulation in Ghana (NASCA Resource Mobilization Report, 2016:13-14, Survey of Small Arms in Ghana, 2014, www.graphic.com.gh).

From this figure, assuming the stock of guns is properly classified for the purposes of revenue collection, it can be alleged that the government collected a decent amount of money for gun importation, issuance and registration in the period in which the data was collected and aggregated.

Returning to the issue of confused statistical basis, the 2014 study was reported to be a baseline study, although the Commission itself has reported in various publications other baseline studies such as the 2006 Baseline on Small Arms in Ghana, NASCA. Another study, probably a pilot was conducted in 2004 was the National Plan of Action to Combat the Proliferation of SALW, (Aning, 2005). This was cited in the period report of the Commission for 2010-2015 NASCA (NASCA Resource Mobilization Report, 2016: pp. 13-14).

There is obvious confusion about the several baseline studies about the same phenomenon. Such a situation does create problems of estimation of gun inventory in the nation. Baseline study, as it is understood in the research and scientific communities refers to "measurements of key conditions (indicators) before a project begins, from which change and progress can be assessed. It helps to set achievable and realistic indicator targets and informs project management decision-making, by providing a reference point to determine progress and adjust project implementation to best serve people in need. It also provides a point of assessment and measurability of the selected indicators and upholds accountability, informs impact evaluation. The specific methodology will depend on a variety of project-specific factors, ranging from specific indicators to time and budget" (IFRC Planning \& Evaluation Department - May 2013).

Still on the bad statistics against which major national policies are been advanced to clip the civil liberties of the people, in the 2014 survey, it was reported that 1.1 million of the Small Arms out of the 2.3 million inventory, were possessed illegally by civilians. The 2004 pilot or maiden study, also established that there were 240,000 guns in circulation.

Although 2004 and 2014 are two distinct periods, there should have been an 
attempt to explain the reasons for the growth in gun possession and calibrated against crime statistics, domestic violence statistics and inter-personal violence statistics in general. The figures, according to the current research, shows alarming increases of over 850 per cent in 10 years, which to all intents and purposes, could be discounted as fallacious?

The Commission has reported that most of the crimes of armed robberies and others were committed with homemade shod off, single barrel guns. If the local gun makers are actually producing so many of these guns in Ghana, shouldn't their outfits be listed among the top one hundred companies in the nation!

\subsection{The Lack of Correlation between Licensed and Registered Guns and the Uptick of Crime in the Urban, Rural and Peri-Urban Areas}

This discussion is also illustrative of the fact that Ghana really does not know how many Small Arms are actually in circulation at any given time, let alone the quantum of ammunitions of various calibers that are in the hands of the citizens. The figures being bandied in the grey literature and appearing rather frequently in peer reviewed papers on the matter since the publication of the 2014 Baseline Study of NACSA and in the Commission's reports were inspired by statistical estimates or approximations. Reliance on geometric progression is a dicey matter particularly when the estimates are couched as absolute numbers or used as absolute values. There are many issues with doing baseline study to estimate incidence and prevalence rate of a phenomenon using cross-sectional, quantitative approach. One of such challenges, is the self-reporting nature of the questionnaire administered. It may face the respondents' ability to be truthful, or their difficulty in expressing the true nature of their gun ownership status and thus leading to poor data acquisition and characterization. It is well known that gun represents power. Like employee salaries, it has been found that workers often lie about their true salary status in social settings and in responding to general surveys. Since guns strongly associate with power and ego, it is also possible that those who may not even own a gun may report otherwise. For researchers, however, there is no other alternative method for such surveys. Therefore, projections from such data cannot be the standard for measurement for gun ownership. Despite the inherent limitations, cross-sectional studies are still useful in educating the public about incidence and prevalence rates of phenomena under investigations (Horowitz, et al., 2001; Kuyper \& Vanwesenbeeck, 2003).

For these reasons, it is important to bear in mind that, the quantum of guns alleged to be in circulation in Ghana, (which is the source of our collective angst and even real fear of potentially becoming victims of gun wielding criminals), is based on extrapolation and projections from the 2014 Baseline Study of NASCA. It is not based on absolute figures on gun ownership. For example, it was reported by Pokoo et al. (2014) that between 1981 and 2013, the Police Firearms Bureau registered 1,236,128 guns to civilians. Yet in the last 10 years, less than 35,000 guns were renewed in each year. In 2005, however, 61,778 guns were re- 
ported by the same study to have been renewed. The number of first time gun registrants fell from 211,581 in 2003 to a miserably low figure of 2,313 in 2013 (Pokoo et al. 2014; Police Service Statistics of Registered Firearms: CID/CFR/ SF.1/V.3/).

On the issue of proliferation of guns in the country, Pokoo et al. (2014) reported that $17 \%$ of the respondents of that study claimed to own guns. Therefore, based on the national population of $24,658,823$ million people, approximately $4,192,000$ representing $17 \%$ of the population owned guns. The 4.2 million gun ownership included non-adult population of the nation allegedly and incredibly also owning guns. How is that possible?

To isolate the adult population owning guns from the non-adult population, the data had to be triangulated with the percentage of adults in the 2010 Census imbedded in the $17 \%$ overall gun ownership. This gave a figure of 2,317,491 gun owners which then was translated as representing actual guns, and therefore giving us the total overall guns in circulation to be 2.3 million in the country (Pokoo et al. 2014:5). From the point of view of academic research, the approach is, perhaps, allowable but as a pragmatic matter, this is simply divorced from real life. It does not represent real inventory of the stock of guns in the hands of the citizens. The reliability of the alleged 2.3 million guns in circulation, is found in statistical correlates with no real evidence with respect to actual stock of guns in the hands of the people, including even criminal and illicit guns. As Gunner Myrdal once said, correlations are not explanations and therefore, basically, such correlates are useless without more (Myrdal, 1957, 1969).

Why didn't the authors of the now famous and widely relied upon 2014 baseline study on Small Arms in Ghana rest at the raw 17\% figure of 4.2 million guns rather than choose the lesser figure of 2.3 million representing, allegedly, adult gun ownership? What happened to the approximately 2 million guns supposedly in the hands of the gun brandishing youth or non-adults? Such a large statistical cache of guns cannot methodologically be ignored, given the huge significance it represents. The wholesale acceptance of the outcome of the baseline study of 2014 and without serious media or academic interrogation, is due to the risk and fatalities of gun related injuries or attacks. The other aspect of the wholesale acceptance of the data is due to the source and authorship of the study. The study was carried out on behalf of the National Commission on Small Arms, by the Kofi Annan International Peacekeeping and Training Center (KAIPTC) in collaboration with UNDP and others.

"In analyzing risk communication, these factors are essential: the sender, receiver, channel and the message are to be considered. The other factors in the information processing framework focus on the receiver and lays out the modalities for a successful communication stream. The goal of risk communication or warning is to prepare the intended community of the warning against the danger and enhance safety, in this case the danger posed by Small Arms" (Slovic, 2000; Glik, 2007; Norman et al., 2012). In the case of the 2014 Baseline study on Small 
Arms, all the elements (high-hazard and high-outrage) for wholesale acceptance of the statistics of the stock of guns in circulation were present. 'There are four main types of risk communication, namely, high-hazard with low-outrage (which is normally used in public relations communications. In the first type of risk communication, the audience is apathetic and uninterested about the risk although it may be a huge risk to all, such as the current public discourse on climate change and its consequences. For example, fire risks is high and concerns all but there appears to be very low-outrage of the public towards it (Glik, 2007; Norman et al., 2015).

The second deals with medium-hazard, medium-outrage, which is preferred by stakeholders to a common cause, such as disruptive power outage during business and manufacturing hours.

The third is low-hazard, high-outrage, where a small group of perhaps, fanatics, may weigh and agitate heavily on an issue such as prostitutes and johns on a school street, as the majority of the community adopts a wait-and-see attitude. The last is the high-hazard, high-outrage such as illicit guns in the country. In this situation, the audience is huge; there is fear, perhaps, anger and willingness to do "something" so that the risk would not happen again. This calls for crisis communication to help the public deal with the circumstances surrounding the event (Glik, 2007, In Norman et al., 2014).

As part of risk communication, the baseline study on the quantum of Small Arms in circulation in Ghana appears to have achieved its goal. However, one may not cry wolf, when there is no such threat (Norman, 2013). The statistics on guns in circulation brings the reader to the main purpose of establishing the $\mathrm{Na}$ tional Commission on Small Arms. The purpose was to create credible controls to manage the potential abuses by gun owners with such deadly weapons or tools with the view of enhancing public security and personal safety. The frequent television display of guns recovered from captured criminals and criminal gangs by the Police, affirms the preposition that the National Commission on Small Arms does not have the ability to know who owns a so-called illicit gun, and that, perhaps, many of its programs may not be effective in bringing us closer to ascertaining the real numbers of illicit or unregistered guns.

It also shows that the Commission since its inception does not have the capacity to triangulate the location of owners with legal Small Arms with the perpetration of gun assisted crimes in those localities. Its reports do not show the nexus between crimes that were committed with legal arms as opposed to illicit arms.

What seems to be evolving from the reports and publications of the Commission is that, there is no real crystalized data on Small Arms that are in compliance with the law and those that are artificially classified as illicit. There is no stratification of the inventory of Small Arms by age of sale or purchase, or even manufacture, or make, or caliber. Even among small hand guns, there are different calibers with different explosive yields and trajectories of the bullets used. Reading the Commissions Survey on Small Arms appears to show that, little 
consideration was given to the possibility that guns that are in compliance could shortly fall into illicit status and verse versa. The constant ebb and flow of what is legal and what is illicit gun ownership effect of the law and the administrative controls, required of the Commission to design the modalities to cure this defect in the law and thus enhance data credibility and accountability. In a word, the distortion in the statistics of gun ownership is partly attributable to the short ownership renewal cycles and the automatic classification of guns with late renewals as illicit. The use of such poor nomenclature and classification undermines the citizens' right to keep and bear arms.

\subsection{The Correlation between Illicit, and Expired Guns and the Uptick of Crime in the Urban, Rural and Peri-Urban Areas}

Knowing the relationship between illicit or expired guns and the uptick of crime in the enumerated areas of the nation would help in the design of the strategies to combat crime. There is often hue and cry over the growing crime rate without scientific basis. When it comes to disasters and emergencies that confront the nation, it appears, the reaction by the population is a persistent preference for alarmist, falling fire and brimstone, end time approach rather than deliberative and scientific approach.

In the present case, the analysis of the taxonomy of crimes being committed and the demography of the victims, and the antecedence of the perpetrators, coupled with exogenous factors contributing to crimes in general has not received deep investigative research. The hysterias associated with well-publicized robberies and crimes create unreasonable fear among the people and may contribute to vigilantism. It is essential for the Commission to design clear guidelines for collecting, assessing, and aggregating data on crime and their relationships to Small Arms in the nation.

One of the ways to achieve a more rational approach to delinking willy-nilly crime rate and gun ownership is to collect close to perfect record of gun ownership and registration and allow a longer renewal period of about two to three years. This would allow the Commission and the Police to trace the number of a particular cohort of gun owners that may engage in crimes with their guns. This would also allow the Commission and their stakeholders' breathing space to conduct good investigations into crimes, and reduce the volume of the artificially created stock of illicit guns in circulation.

\subsection{Owner Notification of Renewal Program vis-à-vis the Alleged Proliferation of Illicit Guns in the Nation}

The Commission would do well to institute what this author calls, Gun License Renewal Notification Program (GLRNP). This can be achieved at little or no cost to gun owners and boost gun registration and thus enhance government revenue on licensing. This can be executed by using either SMS text messaging, conventional mail reminders to those owners with valid postal addresses, email and the Commission's own electronic renewal alert platform. As it has already been said 
in this paper, renewal of guns at $31^{\text {st }}$ December of each year appears not to be working and enhancing gun re-registration. Therefore, the modality for this activity needs to be changed, since the very intrusion of government in gun ownership compromises the right of the citizens to keep and bear arms. As a constitutional priority to all citizens, expedited registration and renewal of guns to citizens is part of the essential attributes of democracy in Ghana.

\section{Conclusion}

The framers of the 1992 Constitution envisioned the potential continuation of the disruptive phenomena of military take-over of duly elected and installed governments in the nation, if not in Black Africa as a whole. In anticipation therefore, it provided for the defense of the nation by every abled bodied citizen of the nation, to resist the potential oppressors' might by keeping and bearing arms.

It is about time the nation stopped scaring its self into believing that there are guns and light weapons everywhere. This review has found that, in fact, the total number of guns that are alleged to be in circulation is not, and cannot be convincingly shown that it is 2.3 million actual guns. In fact, this figure came out of loose projections from a study which may not relate to reality of gun ownership in Ghana. Part of the reasons why that figure is often cited is the way the national media made noise about it, without subjecting the entire study to a review. But the 2.3 million figure does not relate to reality, because at best, the actual figure of Small Arms in Ghana is definitively unknown.

It is recommended that the sales points of guns should be the domain of private enterprise, and should not be shrouded in secrecy. That, the Police's role in ensuring the right to bear arms subsumed in Article 3 and 4 of the 1992 Constitution, should be limited to background investigation to avoid conflict of interest issues in gun acquisition in Ghana. This paper is intended to inform policy and bring sanity to the way data on Small Arms is collected, analyzed and disseminated.

\section{Conflicts of Interest}

The author declares no conflicts of interest regarding the publication of this paper.

\section{References}

(1689). English Bill of Rights.

(1875). United States v. Cruikshank, 92 U.S. 542.

(1886). Presser v. Illinois 116 U.S. 252.

(1922). Arms and Ammunitions Ordinance (Cap. 253).

(1962). Arms and Ammunitions Act (Act 118).

(1962). Arms and Ammunitions Regulation (L. I. 200).

(1962). State Secrets Act (Act 101). 
(1972). Arms and Ammunitions (Amendment) Act (N. R. C. D 9).

(1972). Explosives Regulation.

(2006). Minerals and Mining Act (Act 703).

(2007). Ghana National Commission on Small Arms (Act 736).

(2008). District of Columbia v. Heller, 554 U.S. 570.

(2010). McDonald v. City of Chicago, 561 U.S. 742.

(2016). Caetano v. Massachusetts, 572 U.S.

(2016). NASCA Resource Mobilization Report, Ghana (pp. 13-14).

Agbozo, G. E. (2016). Revisiting Ghana’s Handling of Fire Arms Regulations.

https://www.modernghana.com/news/508979/revisiting-ghanas-handling-of-firearms-r egulations.html

Customs and Excise and Preventive Service Management Law of 1993.

Ecowas (Abuja) Convention on Small Arms and Light Weapons, Their Ammunition and other Related Material of May, 2006.

Glik, D. C. (2007). Risk Communication for Public Health Emergency. Annual Review Public Health Journal, 28, 33-54. http://www.arjournals.annualreviews.org

Gockel, A. F., \& Vormawor, D. (2004). Trade Union Country Reports: The Case of Ghana. Friedrich Ebert Stiftung.

Halbrook, S. P. (1994). That Every Man Be Armed: The Evolution of a Constitutional Right (Independent Studies in Political Economy) (p. 8). Oakland, CA: The Independent Institute.

Horowitz, S. M., Weis, D. L., \& Laflin, M. T. (2001). Differences between Sexual Orientation Behavior Groups and Social Background, Quality of Life, and Health Behaviors. Journal of Sex Research, 38, 205-218. https://doi.org/10.1080/00224490109552089

Kates, D. (1983). Handgun Prohibition and the Original Meaning of the Second Amendment. Michigan Law Review, 82, 204-273. https://doi.org/10.2307/1288537

Kopel, D. (1995). “It Isn't about Duck Hunting: The British Origins of the Right to Arms". Michigan Law Review. Michigan Law Review Association, 93, 1333-1362.

Kuyper, L., \& Vanwesenbeeck, I. (2003). Examining Sexual Health Differences between Lesbians, Gay, Bisexual, and Heterosexual Adults: The Role of Socio-Demographics, Sexual Behavior Characteristics, and Minority Stress. Journal of Sex Research.

Leith, J. C., \& Söderling, L. (2003). Ghana-Long Term Growth, Atrophy and Stunted Recovery. Research Report No. 125, Nordiska Afrikainstitute.

Minerals and Mining Regulation of 2012, (L. I. 2177).

Myrdal, G. (1957). Economic Theory and Underdeveloped Regions. London: Gerald Duckworth and Co.

Myrdal, G. (1969). Objectivity in Social Research. New York: Pantheon Books, 3-5.

Norman, I. D. (2017). Democracy and Choice: Do These Mean Anything to the Average Ghanaian? Advances in Applied Sociology, 7, 115-135.

Norman, I. D., \& Aviisah, M. A. (2015). Does Corruption Manifest Post Traumatic Stress Disorder? Donnish Journal of Neuroscience and Behavioral Health, 1, 12-20. http://donnishjournals.org/djnbh

Norman, I. D., Aikins, M., \& Binka, F. N. (2012). Earthquake Hoax in Ghana, Exploration of the Cry Wolf Hypothesis. Journal of Public Health in Africa, 3, 52-58.

Norman, I. D., Aikins, M., Binka, F. N., \& Awiah, B. (2015). Review of Catastrophic Fires and Risk Communication, Ghana. Advances in Applied Sociology, 5, 167-177. 
Osei, A. (1999). Ghana: Recurrence and Change in a Post-Independence African State. Peter Lang Publishing.

Police Service Statistics of Registered Firearms: CID/CFR/SF.1/V.3.

Slovic, P. (2000). Informing and Educating the Public about Risk. In P. Slovic (Ed.), The Perception of Risk (pp. 192-198). Sterling, VA: Earthscan.

Survey of Small Arms in Ghana, 2014. www.graphic.com.gh https://www.kaiptc.org 